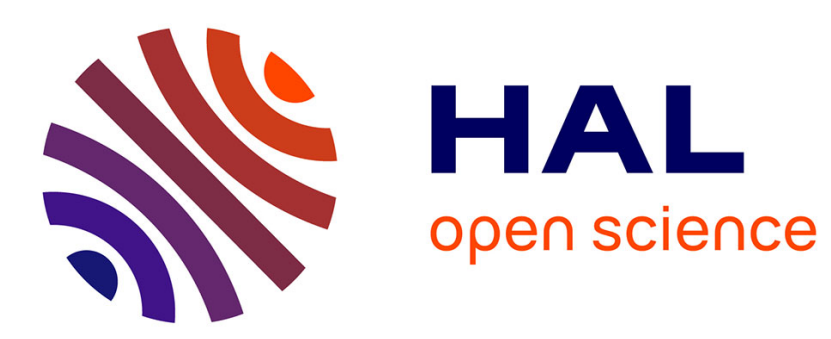

\title{
SALADPLAN: a model of the decision-making process in lettuce and endive cropping
}

Mireille Navarrete, Marianne Le Bail

\section{To cite this version:}

Mireille Navarrete, Marianne Le Bail. SALADPLAN: a model of the decision-making process in lettuce and endive cropping. Agronomy for Sustainable Development, 2007, 27 (3), pp.209-221. 10.1051/agro:2007009 . hal-02666987

\section{HAL Id: hal-02666987 https://hal.inrae.fr/hal-02666987}

Submitted on 31 May 2020

HAL is a multi-disciplinary open access archive for the deposit and dissemination of scientific research documents, whether they are published or not. The documents may come from teaching and research institutions in France or abroad, or from public or private research centers.
L'archive ouverte pluridisciplinaire HAL, est destinée au dépôt et à la diffusion de documents scientifiques de niveau recherche, publiés ou non, émanant des établissements d'enseignement et de recherche français ou étrangers, des laboratoires publics ou privés.

$$
\text { Copyright }
$$




\title{
SALADPLAN: a model of the decision-making process in lettuce and endive cropping
}

\author{
Mireille NAVARRETE ${ }^{\mathrm{a} *}$, Marianne LE BAIL ${ }^{\mathrm{b}}$ \\ a INRA Unité d'Écodéveloppement, Site Agroparc, 84914 Avignon Cedex 09, France \\ ${ }^{\mathrm{b}}$ INAPG, UMR SADAPT, 16 rue Claude-Bernard, 75231 Paris Cedex 05, France
}

(Accepted 22 February 2007)

\begin{abstract}
Market gardeners are facing new environmental, commercial and safety requirements and regulations that weigh heavily on their crop planting and management decisions. Producing high-quality products and simultaneously reducing the use of chemical products needs change in the multi-field planning of crops. In order to identify which cropping practice may be altered depending on each farm's characteristics, we built a rule-based model that represents how market gardeners plan cropping cycles of lettuce and endive, here denoted as salad vegetables, on a farm scale. The model is adapted to the specificities of salad vegetable crops in the Mediterranean region, in particular the combination of several cycles per year and of open field and sheltered crops. The output variables are the developed areas allocated to the different salad types and the range of the harvest dates, which are two key factors for commercialisation. The model is based on identifying the successive decision steps of growers when building their farming systems; descriptive variables are the effective surface area and period for salad cultivation, the number of salad cycles per year, the developed surface area of each salad type and the dates of harvest. The decision-making rules leading to each descriptive variable are based on the agronomic characteristics of soil, climate and crops, farmers' strategic objectives and organisation of farm resources. The cropping decisions were recorded in 38 farms in the large market-gardening region of Languedoc-Roussillon. In the sample, the number of salad types cultivated per farm varied from 1 to 8 and the harvesting period from 3 to 7 months. Our results demonstrate that the model can explain a substantial part of this variability, 26 and 28 farms among 38, respectively, being correctly classified by the model for the two variables. The original result of this work is to enhance the generality of a similar framework built earlier for arable cropping systems. From a practical point of view, this model can be used to determine the leeway available to the farmers for the introduction of technical change in salad cropping. It could therefore be used by agricultural advisors to plan salad crops either for individual farms or on the scale of a marketing structure.
\end{abstract}

lettuce / endive / sheltered crop / decision / model / planning

\section{INTRODUCTION}

Farmers are facing new environmental, commercial and safety requirements and regulations that weigh heavily on their crop planting and management decisions. Market garden crops are particularly emblematic of these changes. Market gardeners are subject to social and regulatory pressure to reduce the use of fertilisers, and at the same time are under commercial pressure to produce high-quality products.

To evaluate to what extent farmers can adapt their cropping systems to these new requirements, we need to identify the factors that impact on the technical performance of cropping systems. We also need to identify the mechanisms by which the cultivation techniques are brought into operation on farms (Sebillotte and Soler, 1990). This key step in the agronomic approach relies on analysing to what extent farmers have the technical and organisational leeway available to modify their systems on plot and farm levels, and even on a larger territorial scale (Navarrete et al., 2006). This also means identifying which factors mainly determine the diversity observed in

* Corresponding author: navarret@avignon.inra.fr strategic and technical choices in farms, in order to later simulate and test innovations in a large range of farming systems.

Such modelling is quite different from the models classically developed as "decision support models" where farmers' decisions are introduced, e.g. by way of a particular module of a crop model. Some of them are "research oriented". In Jones et al. (2003), for example, the "management module" which includes modalities (dates and doses) for planting, harvesting or applying fertilisers is completed by the user on the basis of experimental data. The model is used to estimate the climatic and soil influence on crop performances for various regions. A farmer's representation of the technical management is not really needed. For the models designed as a direct aid to crop management at farm level, an "action plan" is formulated in the form of "if-then" decision rules (Carberry et al., 2002; Keating et al., 2003, Chatelin et al., 2005). But, even in such cases the determining factors of those rules, internal or external to the farm, and so, the possibilities to change them are not always taken into account.

In this article, we represent farmer decision-making processes. We refer to management sciences and ergonomic works applied to farming systems (Sebillote and Soler, 1990; Cerf, 1996). Farmers' decisions are recurrent and cyclic and 
can be represented in a dual form; strategic planning and dayby-day decisions, taking into account adaptations in real time. The variables planned by farmers and identified in research on annual arable crops (Aubry et al., 1998; Aubry, 2000; Dounias et al., 2002) consist of the part of farm land allocated to the crop, temporal position and modalities of cultural practices (e.g. equipment and manpower or doses of fertilisers). Farmers identify sets of fields, which are planned according to the same rules: sequencing rules (for chronological order of cultural operations), activation rules (to start and end operations), arbitration rules (to set out the priorities between activities, fields or crops) and rules on modalities of cultural practices. Finally, the factors determining the rules for building and managing not only one crop but cropping systems are considered at the level of the farm; they take into account the farmer's choices for allocating resources such as land (Maxime et al., 1995; Aubry et al., 1998), manpower and equipment (Papy et al., 1988; Chatelin and Mousset, 1997) or water (Leroy et al., 1996). This conceptual framework has been used for various agricultural systems and purposes: for apple orchards to conceive innovations for cultural practices (Nesme et al., 2003); on cotton crops to develop indicators for technical supervision of farmers at a regional level (Dounias et al., 2002), and for management of animal manure to understand the interfarm flows of organic matter (Aubry et al., 2002).

Market gardening has been the focus of far fewer studies. The models built for arable crops cannot be easily adapted to market garden crops because of their special characteristics. Firstly, for such fresh products, spreading the harvest period is crucial to avoid extended storage; for example, the time elapsed between lettuce harvest and sale cannot exceed 2 days. Secondly, cycle lengths are often short (50-120 days for lettuce) and thus allow several successive cycles on the same plot in a single year. Thirdly, production is very labour-intensive as many cropping operations are still performed manually. Fourthly, diversification is increasing, with each subspecies (or type) having its own fairly specific ecophysiological characteristics. These characteristics raise several questions when modelling the decision-making processes: how is this extended production period organised on the farm? How do farmers allocate different types of the same species in a multi-field system to reach both the overall target volume for the species and for each type, and this over time? How do different farm resources (and particularly labour force) impact on these decisions? Finally, as crop sequence was previously modelled on a year-by-year basis, does the presence of several cycles within the same year call into question the decision-making models used for it?

In this article we focus on lettuce and endive production (here denoted as salad vegetables for the sake of simplification) and we analyse how market gardeners plan the crops of the different salad types they cultivate on different plots, either open field or under shelter. We first describe the general structure of the model. Then, using data from a growers' survey in Languedoc-Roussillon, a large market-gardening region in Southeastern France, we analyse to what extent the model accurately reflects the diversity of the ways growers allocate the different salad types between plots and throughout the production period.

\section{MATERIALS AND METHODS}

\subsection{Global considerations of salad production}

The two botanical families, lettuce - genus Lactuca - and endive - genus Cichorium, are divided into several horticultural types relying on differences in leaf colour, size and shape and degree of rosette: butter head lettuce, cos lettuce, batavia, escarole, frisee and also diversified types: oak leaf lettuce and lollos, red and blond, and Très Fine Maraîchère (Ryder, 1999a).

In the Mediterranean area, salad is grown either in open fields or under high plastic tunnels or multispan plastic greenhouses. They are cropped year round except in summer when temperatures are too high for commercial crops. Sheltered crops are planted from September to March. The growing cycles are shorter than in open fields, about 40 days in the autumn and 80 days in the winter, which enables up to 3 cycles per year. Several species are cropped after salad under shelter: short-cycle so-called "spring" crops harvested until June such as courgette and potatoes; and so-called "summer" crops harvested until August or even September such as tomato or cucumber. In the open field, salad is more often associated with potatoes or artichokes.

The Roussillon county in the Eastern Pyrenees plain is a major area for salad production. It accounts for more than half the tonnage of salad produced in Southeast France, which itself accounts for $70 \%$ of national winter salad production. In the last 15 years, shelter areas have increased by $20 \%$, whereas open field areas have diminished by 35\% (Agreste, 2001), except on farms specialised in open field production on a large scale.

\subsection{Data acquisition}

The modelling work on technical management of annual arable crop area (Maxime et al., 1995; Aubry et al., 1998) provided a useful analytical framework to collect data. Several additional variables were included to take into account the salad vegetable characteristics, such as spreading the harvest dates and cropping several crop cycles per plot and per year. The decision rules were built with a bibliography from the available scientific international literature in order to build as generic a model as possible. But some parameters can only be found by consulting people in charge of managing the production, so we also used local articles written by technical advisers or engineers who carry out experiments in Southeast France.

The model was evaluated using survey data from 38 farms. The farms were selected to cover a range in products and general functioning. They include farms combining shelter and open field salad crops and farms cultivating only open field or sheltered salad production. The 33 farms with sheltered crops have already been described in Navarrete et al. (2006). 
Table I. An example of the output variables in the SALADPLAN model.

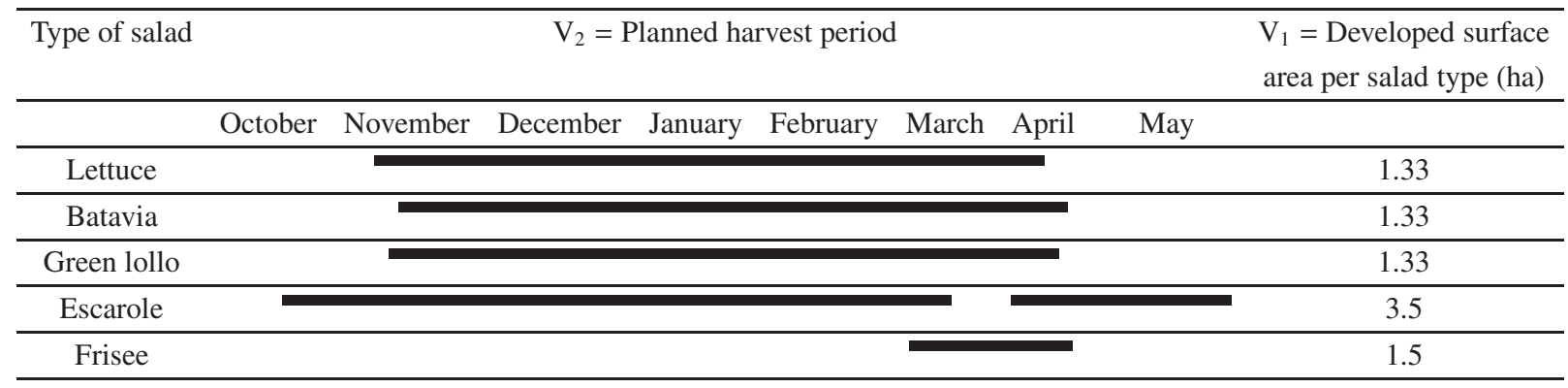

The example in Table I and Figure 2 is taken from farm A2 in the survey.

The areas devoted to salad varied up to 48 ha as open fields and 8 ha under shelter. They belong to 3 farm types (Oniflhor et al., 2000) which are representative of the diversity observed in the Roussillon area: highly mixed farms growing several market garden species along with fruit trees and vines (17 farms), specialised salad farms where the salad area accounts for more than three-quarters of usable area (18 farms), and specialised greenhouse farms where soil-less crops have priority over salad crops (3 farms). The percentage of each type in the sample was representative of the percentage in the Roussillon area.

Each farm survey lasted about 3-5 hours, spread over two visits. A first step concerned the analysis of the overall farm system functioning: family, objectives, history; cropping systems, cropping plan; production means including land, equipment, machinery and labour. Next, the survey addressed more specifically the management of salad production. Each plot was characterised: open field or characteristics of the shelter, salad type, crop sequences with salad, and crop management sequence.

\section{SALADPLAN, A MODEL FOR REPRESENTING MULTI-FIELD PLANNING OF SALAD CROPPING}

The model is based on identifying the successive decision steps of growers when building their farm's technical systems. Farm resources and the hierarchy of the different crops are considered to be both constant and known over a year-long scale. Two major output variables for each type of salad (in$\operatorname{dex} j$ ) are:

- $\mathrm{V}_{1}$ expressed in ha, the developed surface area cropped with salad type $\mathrm{j} . \mathrm{V}_{1}$ is an indication of the overall volume of salad that can be produced every year and takes into account the surface area cultivated with this type of salad and the number of salad cycles per plot and per year.

- and $\mathrm{V}_{2}$ expressed in week number within the year, the range of the harvest dates.

These output variables were defined on the farm scale where they are relevant for growers who seek an overall characterisation of farm production (Tab. I, Fig. 1).
We first describe the key decision-making variables used by growers, called descriptive variables. Then we present the major decision-making rules used to derive each descriptive variable. These rules are based on the agronomic characteristics of soil, climate and crops, on the farmer's strategic objectives and the organisation of farm resources.

\subsection{Descriptive variables of the model and their combination}

When allocating farm land to different arable crops in a given year, decision-making variables of French farmers are the surface areas suitable for cultivation (all plots which, according to the farmer, are suitable for the species considered), crop return time (period deemed acceptable by the farmer before replanting the same species in a given plot) and cropping surface areas (all plots on which this crop is effectively present in a given year) (Maxime et al., 1995; Aubry et al., 1998). These variables mainly depend on the hierarchy between crops, species adaptation to the prevailing soil and climate conditions and the work schedule. The two major restrictions when allocating crops to plots were found to be distance from each plot to the farmhouse and soil characteristics, because arable farms in France are usually very large.

In the SALADPLAN model (Fig. 1), the descriptive variables cited above are included but adapted to the distribution of salad cycles throughout the year and the necessity of staggering the harvesting. Four descriptive variables are used. The index $\mathrm{i}$ represents the different plots on the farm, the index $\mathrm{j}$ the salad types cultivated and the index $\mathrm{k}$ the number of the cycle for a given salad in a particular plot:

- In box A, $V d_{1}$ consists of two variables: $S_{i}(\mathrm{ha})$, the effective surface area of plot i cultivated by the farmer with at least one salad cycle and $P_{i}$ (first-last date in a year), the effective period for salad cultivation on these plots (Fig. 2a, b),

- In box B, $V d_{2}$ equals $N_{-}$Cycles $_{i}$, the number of salad cycles the farmer decides to crop successively on each plot $\mathrm{i}$ (Fig. 2b),

- In box C, $V d_{3}$ equals Type_Dev_S $S_{j}$, the developed surface areas (ha) for each salad type j (Fig. 2c),

- In box D, $V d_{4}$ equals Harvest_Period $i k$, the planned period of harvest on plot i for cycle k (Fig. 2d). 


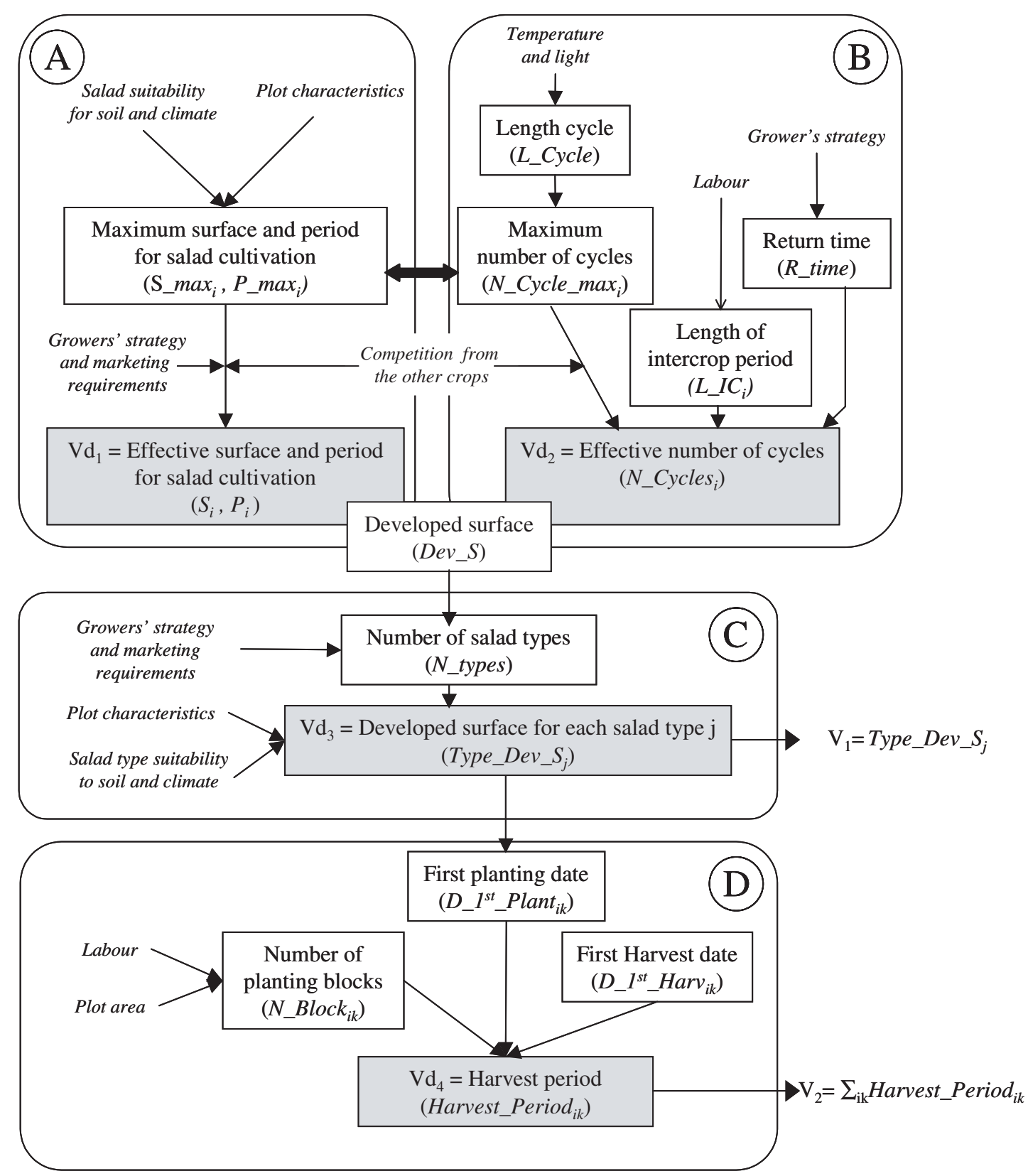

Figure 1. General structure of the model for multi-field planning of salad cropping. The four boxes A-D represent the successive steps for predicting the two output variables, $\mathrm{V}_{1}$, the developed surface area devoted to each salad type and $\mathrm{V}_{2}$, the harvest period. The intermediate variables are framed. The input variables are written in italic characters.

The decision-making process generally starts by determining which plots will be devoted to salad with regard to other crops present on the farm, i.e. by determining $V d_{1}$ and $V d_{2}$. The variables do not refer to salad types because in the decisionmaking process the variation between types is minor in comparison with other factors that determine the surface and period of salad cultivation and the number of cycles. Once $V d_{1}$ and $V d_{2}$ are fixed, the next step of the model is to determine the number of salad types to be cropped and their allocation to the salad plots. If for a particular type of salad the farm has entered into a commercial contract, the farmer may start by defining the plots and production periods for this particular type, then adjust the plots for the other types subsequently.

\subsection{Decision rules and factors that determine descriptive variables}

Dogliotti et al. (2003) identified in the literature several methods employed to set the parameters of crop rotation models: surveys providing historical data for farmer rotation practices (El-Nazer and McCarl, 1986), experimental data 
(a)

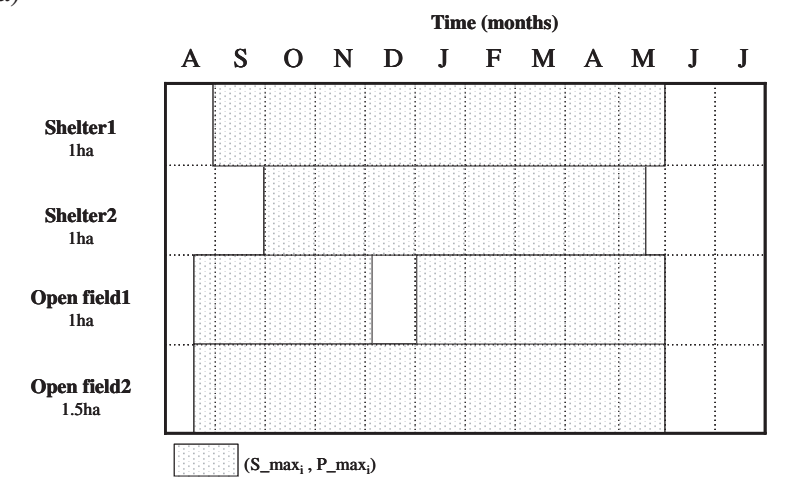

(c)

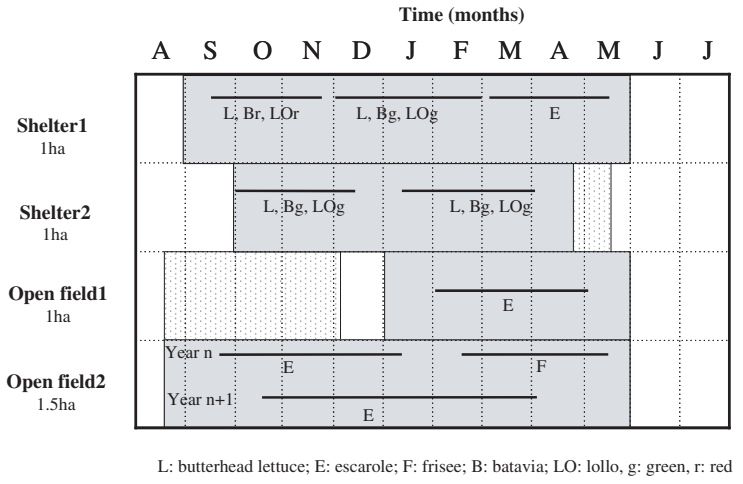

(b)

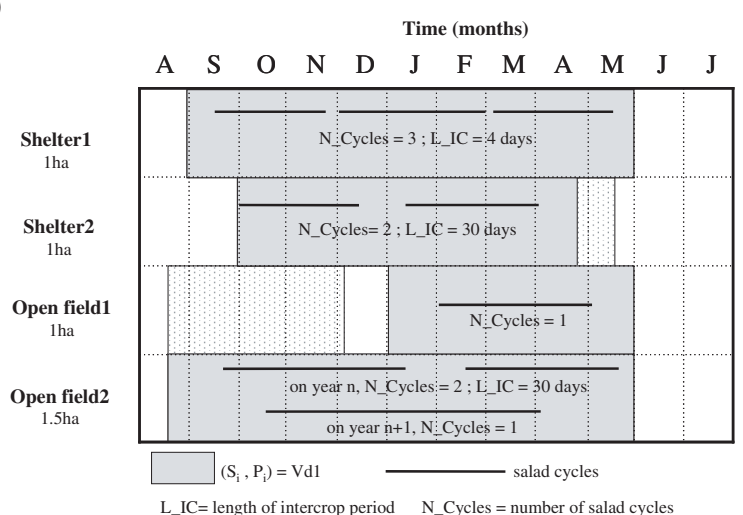

(d)

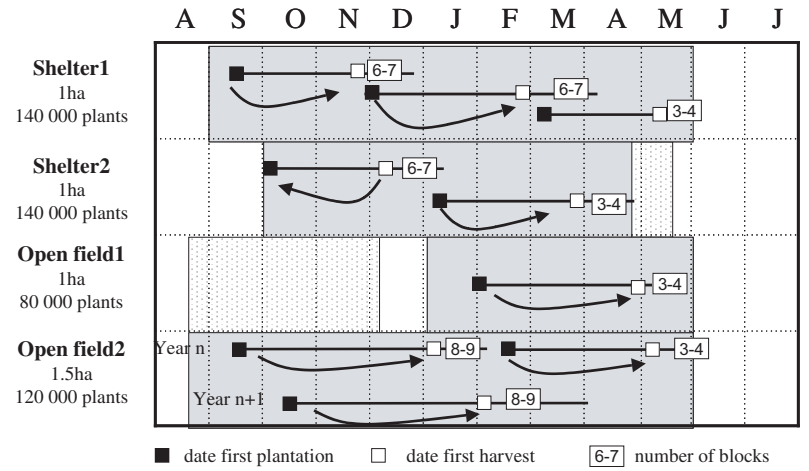

Figure 2. An example of decision variables on farm $\mathrm{A}_{2}$. a. Maximum surface area and period suitable for salad cultivation as determined by agronomic restrictions. Shelter1: multi-tunnel with efficient ventilation, enabling cropping from September to May. Shelter2: low tunnel where cropping in September and last fortnight of May is not feasible because of excessively high temperatures. In open fields, planting can start earlier in autumn than in shelters but is not feasible in winter; well-rooted salads usually tolerate moderate cold (e.g. Open field2), except in Open field1, where salad must be harvested before December. b. Effective surface and period for salad cultivation in relation to farm restrictions and number of salad cycles. In Shelter1, three successive salad cycles are cultivated, whereas in Shelter2, the period for salad cultivation is reduced by cucumber planting in April, thus permitting only 2 salad cycles. c. Distribution of salad types over total salad area. d. Planting and harvesting dates. The arrows indicate the first decision forcing the next one (e.g. for the first cycle of Shelter2, the grower decides the harvesting date and then infers the planting date). Labour force available on the farm enables 20000 salads to be harvested per week. The number of blocks is calculated to do all manual tasks in due time (e.g. in January, end of Shelter2 harvesting, beginning of Open field2 harvesting and Shelter2 second cycle planting).

and ecological concepts (Rossing et al., 1997; Ten Berge et al., 2000), and expert knowledge (Dogliotti et al., 2003). In SALADPLAN, the decision rules come from the technical and scientific bibliography of salad cropping. Here, we will successively address agronomic, strategic and organisational factors involved in the decision-making process.

\subsubsection{Definition of salad surface area and cropping period $\operatorname{Vd}_{1}$ (Fig. 1, Box A)}

\section{Agronomic factors used in decision-making (Fig. 2a)}

The maximum surface area suitable for salad cultivation $\left(S \_\right.$max $)$is the sum of areas of each individual plot suitable for salad $\left(S \_\right.$max $\left._{i}\right)$. Salad is relatively tolerant of different soil and climate conditions (Tab. IIa). And, in intensive market gardening and more particularly under shelter, certain un- favourable soil and climate conditions can be corrected by appropriate equipment or cropping practices. In this study, which was conducted on an irrigated alluvial plain in a Mediterranean climate, it was considered that the areas of all the plots could sustain at least one salad cycle.

The period suitable for salad cultivation $\left(P \_\right.$max $)$depends essentially on the type of climatic control in the different plots considered for $S \_$max calculation. Table IIb gives the values of this parameter in Roussillon: for example, for open field plots prone to frost, salads must be harvested before December and not planted until the end of January.

Strategic and organisational factors used in decisionmaking (Fig. 2b)

The effective surface area and period suitable for cultivation $\left(V d_{1}\right)$ result from arbitration rules because of 
Table II. Agronomic rules determining S_max and P_max.

(a) Maximum surface area suitable for salad cultivation ( $S \_$max)

$S \_$max $=\sum\left(a_{i} S \_\max _{i}\right)$ with $\mathrm{a}_{i}=1$ if the soil and climatic conditions described below are met on Plot $\mathrm{i}$ and $\mathrm{a}_{i}=0$ if not

Soil characteristics for salad cultivation on Plot i:

Soil loose to $30 \mathrm{~cm}$, dries easily, $\mathrm{pH}>6$ and low salinity,

or $\quad$ Soil $=\mathrm{pH}<6$ but soil liming performed

or $\quad$ Soil $=$ high salinity but soil leaching performed

Climate characteristics for salad cultivation on Plot i:

Minimum air temperature $>-5$ to $-10{ }^{\circ} \mathrm{C}$ for first half of cycle and $>0{ }^{\circ} \mathrm{C}$ after heart formation

or $\quad$ Protective plastic sheet placed flat on open field Plot $\mathrm{i}$

or Anti-freezing equipment on sheltered Plot i (heating, roof-spraying)

and In very windy areas, presence of sheltering hedge on open field Plot i

\begin{tabular}{|c|c|c|}
\hline \multicolumn{3}{|c|}{ (b) Maximum period suitable for salad cultivation ( $P \_$max) } \\
\hline \multicolumn{3}{|c|}{$P_{-} \max _{i}=\left[\right.$ first date $_{i}-$ last date $\left._{i}\right]$ for Plot $\mathrm{i}$ and $P_{-} \max =\left[\right.$ earliest first date ${ }_{i}-$ latest last date $\left._{i}\right]$ among all Plots $\mathrm{i}$} \\
\hline If Plot $\mathrm{i}=$ open field & Then & $P \_\max _{i}=[$ mid-August - end of May $]$ \\
\hline \multirow{3}{*}{ If Plot $\mathrm{i}=$ open field and prone to frost } & & and Date_Plant ${ }_{i}<$ end of October \\
\hline & Then & $P \_\max _{i}=[$ mid-August - end of November $]$ \\
\hline & & and [early February - end of May] \\
\hline If Plot $\mathrm{i}=$ tunnels & Then & $P \_\max _{i}=[$ mid-September - mid-May $]$ \\
\hline If Plot $\mathrm{i}=$ multispan plastic greenhouse & Then & $P \_\max _{i}=[$ early September - end of May $]$ \\
\hline
\end{tabular}

Sources: Ryder, 1999a; Chaux and Foury, 1994; Goisque, 1994; Thicoipe, 1997; Lagier, 1994.

competition for labour or land at the farm level (Navarrete et al., 2006). They are therefore dependent upon the relative importance of salad cropping in comparison with other crops. If labour is a limiting factor and, for example, if priority in April is given to the harvesting of glasshouse tomatoes or the thinning of peach trees, then the farmer may decide to shorten the salad-cropping period. If salad is in competition with another species for plot occupation such as the planting of socalled "spring" crops in March-April, the farmer may choose to run the cycle for the crop with the greatest added value, as illustrated in Figure $2 b$ for Shelter2 and Open field1. In other words, if the farm is not specialised in salad, then the saladcropping period is shortened $\left(P<P_{\_}\right.$max $)$. If the farm is specialised in salad, then the actual cropping period corresponds to the longest suitable period $\left(P=P \_\right.$max $)$and all the plots suitable for salad are used for at least one cycle $\left(S=S \_\right.$max $)$. Figure $2 b$ illustrates the case of a farm where only two out of four salad plots have a production period reduced below the maximum possible.

\subsubsection{Determining the effective number of salad cycles $\left(\mathrm{Vd}_{2}\right.$, Fig. 1, Box B)}

The effective number of salad cycles on each plot $\left(N_{-}\right.$Cycles $\left._{i}\right)$ depends on the maximum number of cycles $\left(N_{-}\right.$Cycles_max $\left.{ }_{i}\right)$ possible over the period suitable for salad cultivation as previously defined $\left(V d_{1}\right)$, and strategic and organisational factors.

\section{Agronomic factors used in decision-making}

The maximum number of cycles for Plot i $\left(N \_C y c l e s \_\max _{i}\right)$ depends on the period suitable for cultivation on the plot $\left(P \_\max _{i}\right)$ and the length of each cycle $\mathrm{k}$ $\left(L_{-} C y c l e_{i k}\right)$, with $\sum_{\mathrm{k}} L_{-} C y c l e_{i k}<P_{-} \max _{i}$.

Cycle length from planting to maturity ( $L_{-}$Cycle) is primarily dependent upon average air temperature and, to a lesser extent, solar radiation. Cycle length has been estimated by different authors to be between 500 and 700 degree-days (DD) at threshold $0{ }^{\circ} \mathrm{C}$ for sheltered winter lettuce (de Tourdonnet, 1998), and 600 to $700 \mathrm{DD}$ for open field summer lettuce (Bruno and Papy, 1992). In fact, the harvesting date depends on several other factors, such as the growing process (heart formation, Ryder, 1999b), salad type (the cycle for lettuce is 2-3 weeks shorter than for Batavia, Ryder, 1999b) and soil characteristics (Wurr et al., 1988; Bruno and Papy, 1992). We therefore used synthetic information from technical experts to take account of salad type, cropping practices (open field or sheltered) and planting period. For example, for autumn planting, the period was 40 days under shelter and 50-60 in open fields; for winter planting the period was 80 days under shelter and 100-120 days in open fields (Goisque, 1994; Ryder, 1999b). As a consequence, under the conditions of this study, the maximum number of salad cycles was 3 under shelter and 2 in open fields. 
Table III. Decision-making rules when fixing the intercrop period $L \_I C_{i}$.

\begin{tabular}{lll}
\hline Conditions & Consequence \\
\hline $\begin{array}{l}\text { If the grower's aim is a strict scheduling of planting } \\
\text { and harvesting dates throughout the year }\end{array}$ & Then & $\begin{array}{l}L_{-} I C_{i}=\mathrm{f} \text { (planned labour force and work organisation), } \\
\text { (e.g. } 2 \text { to } 15 \text { days varying on farm) }\end{array}$ \\
\hline $\begin{array}{l}\text { If the grower's aim is to shorten intercrop period } L_{-} I C_{i} \\
\text { to a minimum }\end{array}$ & Then & $\begin{array}{l}L_{-} I C_{i}=\mathrm{f}(\text { actual soil water content at harvest on Plot i) } \\
\text { (e.g. } L_{-} I C_{i}>15 \text { days on clayey soil) }\end{array}$ \\
\hline
\end{tabular}

Source: Survey of producers and evaluation of production costs by the Chamber of Agriculture, Pyrénées-Orientales, France.

\section{Strategic and organisational factors used in decision- making}

The actual number of cycles per plot $\left(N_{-}\right.$Cycles $\left._{i}\right)$ depends on the maximum number of cycles and also on the return time $\left(R_{-}\right.$time $\left.e_{i}\right)$, which is the delay between two successive plantings of the same species on the same plot, and the intercrop period $\left(L_{-} I C_{i}\right)$. These are primarily determined by strategic or organisational factors.

The accepted return time $\left(R \_t i m e_{i}\right)$ is generally the result of a balance struck between the pest risks tolerated and crop profitability. For arable crops, while it is considered that a return to flax after less than six years may cause a reduction in fibre yield (Paul et al., 1991), this return time is about one year for maize monocrops in France. Over the last few years, most market gardeners have employed a very rapid succession of salad cycles. As a consequence, they use different techniques to compensate for the negative consequences of this choice and, for instance, use soil chemical disinfection to control soil-borne diseases. However, since this technique has recently been criticised because of its negative effects on the environment and on product quality, growers are encouraged to increase return times. Some of them crop salad every year on each plot but increase intra-annual return times (Navarrete et al., 2006), either every year ( 2 cycles, whereas 3 are possible) or on average (three cycles in year $n$ followed by one cycle in year $n+1)$. Others, and this mainly concerns organic producers, modify return times between the years (Beliard, 2003) by cropping salad only one year out of two or three.

The intercrop period $\left(L_{-} I C_{i}\right)$ is the time necessary between the harvest of a cycle and the next planting and is intended to prepare the land. Under open field conditions, Dogliotti et al. (2003) considered this to depend mainly on the amount of residues and weeds left by the previous crop, and the expected climate (temperature and rainfall). Under sheltered conditions, Chaux and Foury (1994) indicated average salad intercrop periods of between 1 and 2 weeks. But, if no restrictions are present, a plot harvested on day $\mathrm{n}$ may be tilled on day $\mathrm{n}+1$ and planted on day $\mathrm{n}+2$, because harvesting is the longest task (Thicoïpe, 1997). We considered that work organisation and soil water content are the main determining factors for the intercrop period (Tab. III). In practical terms, in the region studied, if the intercrop period exceeds 15 days, it becomes impossible to crop 3 salad cycles per year in plastic tunnels (cf. Shelter2, Fig. 2b).

Finally, for each plot the sum of the length of the different cycles and the length of the intercrop period determine the actual period used for salad cropping $\left(P_{i}\right)$, thus illustrating the in- teractions between $V d_{1}$ and $V d_{2}$. Moreover, if the farmer aims at a potential volume of salad production (estimated by the developed surface area Dev_S), a reduction in the number of cycles for certain plots $\left(V d_{2}\right)$ may be compensated for by an increase in the surface area used for each cycle $\left(V d_{1}\right)$.

\subsubsection{Developed surface area for each salad type $\left(\mathrm{Vd}_{3}\right.$, Fig. 1, Box C)}

The number of salad types ( $N \_$types) varies according to the developed surface area (Dev_S), market gardener strategy and commercial demands. As marketing structures often demand a minimum volume for each salad type supplied by the grower, $N \_T y p e s$ is strongly linked to Dev_S. Although most farmers who have a large developed surface area cultivate a large number of salad types to reduce agricultural and financial risks, some restrict themselves to conventional species (butter head lettuce, batavia and frisee) that are easy to crop and sell.

In order to define the developed surface area per type (Type_Dev_ $S_{j}$ in ha), the salad types are allocated to cropping surface areas by taking into account the suitability of each salad type to the soil and climate characteristics prevailing on each plot. The types may be divided into 3 groups (Tab. IV). Green lettuces (butter head lettuce, batavia and oak leaf lettuce), being susceptible to frost and wind, are cultivated preferentially under frost-proof shelters (Fig. 2c). In the open field they are cultivated only during favourable periods or on plots not subject to frost and sheltered from the wind. Red lettuces (batavia, oak leaf lettuce and lollo) are more resistant to wind and frost, but their colour renders them highly susceptible to a lack of light. They are therefore not cultivated under shelters, or at least not during the most unfavourable period (December-January) (Shelter2, Fig. 2c). Endives (frisee and escarole) are more resistant to wind and frost than lettuces, but are susceptible to water shortages and high temperatures. They are preferentially cultivated in open fields (Fig. 2c); frisee and Très Fine Maraîchère in particular are avoided on highly sandy permeable soils. Allocating the different salad types is therefore a complex process which involves their positioning both in space and in time as plot suitability varies with cropping period.

\subsubsection{Harvesting period ( $\mathrm{Vd}_{4}$, Fig. 1, Box D)}

At this stage of the decision-making process, it is possible to define approximately the planting periods for each plot. 
Table IV. Species suitability to climatic constraints.

\begin{tabular}{llccccc}
\hline & Salad type & Poor light & Excess heat & Frost & Water shortage & Wind \\
\hline Lettuce & green butter head lettuce & - & - & -- & - & -- \\
& green Batavia & - & -- & -- & - & -- \\
& green oak leaf lettuce & - & -- & -- & - & -- \\
& green lollo salad & - & - & -- & - & - \\
\cline { 2 - 6 } & red Batavia & - & - & - & - & - \\
& red oak leaf lettuce & -- & -- & - & - & - \\
& red lollo salad & -- & - & - & - & - \\
\hline \multirow{2}{*}{ Endive } & Frisee & + & -- & + & -- & + \\
& Escarole & + & -- & - & - & + \\
& Très Fine Maraîchère & + & -- & -- & -- & -- \\
\hline
\end{tabular}

The sign indicates that a particular salad type is resistant (+) or sensitive (-) to a particular climatic constraint. Source: Seigneur (1996) on the basis of technical input from experts.

Table V. Calculation rules to determine the estimated classes for $\mathrm{V}_{1} *$ and $\mathrm{V}_{2} *$.

\begin{tabular}{|c|c|c|c|}
\hline \multirow[t]{2}{*}{ Condition } & \multirow{2}{*}{$\begin{array}{l}\text { Data considered for } \\
\text { calculation (Tab. V) }\end{array}$} & \multicolumn{2}{|c|}{ Values for the estimation } \\
\hline & & $\mathrm{V}_{1} *$ & $\mathrm{~V}_{2} *$ \\
\hline a. Dev_S $=\sum_{i} S_{i} * N \_C y c l e_{i}$ & columns $3,4,8,9$ & & \\
\hline If $D e v \_S \leqslant 3$ ha & & +1 & +2 \\
\hline If 3 ha $<D e v \_S \leqslant 9$ ha & & +2 & +2 \\
\hline If $D e v \_S>9$ ha & & +3 & +3 \\
\hline $\begin{array}{l}\text { b. Farm specialised in salad or soil-less crops (to minimise } \\
\text { the financial risk associated with specialisation) }\end{array}$ & column 5 & +1 & \\
\hline c. Presence of high-tech shelters (enabling 3 cycles per year) & column 8 & +1 & +1 \\
\hline d. No shelter or no open fields on the farm & columns 3-4 & -1 & -1 \\
\hline e. No particular constraint on soil, climate or work organisation & column $10-12$ & +1 & +1 \\
\hline
\end{tabular}

The values for classifying Dev_S (3 and 9 ha) were chosen as they separate the sample into 3 parts (one-quarter of the sample having less than 3 ha and one-quarter having more than 9 ha).

If the sum of the lines a to e is equal to 0 or 1 , then the farm belongs to the estimated class I; if the sum is 2 or 3 , it belongs to class II, if the sum is 4 to 6 , then it belongs to class III. Example for farm $\mathrm{A}_{7}$ : the sum for $\mathrm{V}_{1} *$ is $+2+0+0-1+1=2$ and for $\mathrm{V}_{2} *+2+0+0-1+0=1$, thus the farm belongs to estimated class II for $V_{1} *$ and estimated class I for $V_{2} *$.

However, this does not by any means indicate the harvesting period $\left(V d_{4}\right)$ on each plot which depends, for each plot $i$ and each salad cycle $k$ on the plot, on the first planting date $\left(D \_1^{\text {st }}\right.$ Plant $\left._{i k}\right)$, number of planting blocks $\left(N \_\right.$Blocks $\left.s_{i k}\right)$ and first harvest date $\left(D_{-} 1^{\text {st }}\right.$ Harv $\left._{i k}\right)$. These variables are based on the sequencing rules which describe the logical sequence of planting and harvesting actions at the farm level. Here we use the formalism put forward by Aubry (2000), which positions the various farming operations in time on the basis of activation/termination rules (start/end of an operation), sequencing rules (chronological order of operations on a plot) and arbitration rules (priority between plots).

When selecting first planting dates $\left(D_{-} 1^{\text {st }}\right.$ Plant $\left._{i k}\right)$, two sequencing rules are possible:

- If the market gardener wishes to maximise the number of cycles on Plot i, it is the date on which the first cycle is planted (the earliest possible date given the available equipment, refer to cropping period $P_{i}$ ) which determines subse- quent events such as its harvesting date, the date on which the following cycle is planted after consideration of the intercrop period $L_{-} I C_{i}$, and so on (Shelter 1 in Fig. 2d).

- By contrast, if the market gardener wishes to produce for a given date (e.g. in December-January as shown in Shelter2, Fig. 2d for commercial reasons), this harvesting date determines the dates on which the different cycles are planted, even if the maximum number of cycles cannot be attained.

In the absence of a clearly defined biological indicator for maturity, the first harvest date $\left(D_{-} I^{\text {st }} H_{a r v_{i k}}\right)$ is that on which the required size is reached and for lettuce the heart is fully formed. The grower then has 7 to 10 days for harvesting and this constitutes a termination rule as beyond this timeline the salad may elongate, the heart may open and necrosis may appear on the leaves (Thicoipe, 1997). Because endives do not form a heart, they may be harvested over a longer period, up to one month (Chaux and Foury, 1994), the date in such cases being mainly dependent upon the state of the market. However, 
Table VI. Farm characteristics of the survey.

\begin{tabular}{|c|c|c|c|c|c|c|c|c|c|c|c|}
\hline \multirow{3}{*}{ Farm } & \multirow{3}{*}{$\begin{array}{c}2 \\
\text { Total } \\
\text { area } \\
\text { (ha) }\end{array}$} & 3 & 4 & 5 & \multirow{3}{*}{$\begin{array}{c}6 \\
\text { Harvest } \\
\text { period } \\
\text { (months) } \\
\left(\mathrm{V}_{1} *\right)\end{array}$} & \multirow{3}{*}{$\begin{array}{c}7 \\
\text { Number } \\
\text { of salad } \\
\text { types } \\
\text { (N_type } \\
=\mathrm{V}_{2} * \text { ) }\end{array}$} & \multirow{2}{*}{\multicolumn{2}{|c|}{$\begin{array}{c}8 \\
\\
\text { Max. number of } \\
\text { salad cycles } \\
\text { (N_Cycles) }\end{array}$}} & \multirow{3}{*}{$\begin{array}{c}10 \\
\text { Restrictions } \\
\text { on production } \\
\text { period }\end{array}$} & \multirow{2}{*}{\multicolumn{2}{|c|}{$\begin{array}{l}11 \\
\text { Restrictions } \\
\text { on salad types }\end{array}$}} \\
\hline & & \multicolumn{2}{|c|}{$\begin{array}{l}\text { Salad area } \\
\text { (ha) }\end{array}$} & \multirow[t]{2}{*}{ Crops } & & & & & & & \\
\hline & & $\begin{array}{l}\text { under } \\
\text { shelter }\end{array}$ & $\begin{array}{l}\text { open } \\
\text { field }\end{array}$ & & & & $\begin{array}{c}\text { under } \\
\text { shelter }\end{array}$ & $\begin{array}{l}\text { open } \\
\text { field }\end{array}$ & & in space & in time \\
\hline $\mathrm{A}_{1}$ & 6 & 0.5 & 1.0 & Fruit & 8.0 & 8 & 3 & 2 & 0 & 0 & 0 \\
\hline $\mathrm{A}_{2}$ & 10 & 2.0 & 2.0 & Fruit & 7.7 & 5 & 3 & 2 & 0 & 0 & 0 \\
\hline $\mathrm{A}_{3}$ & 3.5 & 2.0 & 1.5 & Salad & 5.3 & 6 & 2 & 1 & soil & labour & labour \\
\hline $\mathrm{A}_{4}$ & 3.5 & 3.5 & 0 & Salad & 7.0 & 7 & 3 & 0 & 0 & shelter & 0 \\
\hline $\mathrm{A}_{5}$ & 3.5 & 0.3 & 0.5 & Fruit & 5.7 & 6 & 3 & 2 & 0 & labour & labour \\
\hline $\mathrm{A}_{6}$ & 2 & 0.4 & 0.1 & Fruit & 4.3 & 4 & 2 & 1 & crop & soil & 0 \\
\hline $\mathrm{A}_{7}$ & 3 & 0 & 3 & Vegetables & 6.0 & 4 & 0 & 2 & crop & 0 & 0 \\
\hline $\mathrm{A}_{8}$ & 14 & 1.5 & 11.0 & Salad, Fruit & 6.0 & 8 & 2 & 1 & labour & $\begin{array}{c}\text { wind, shelter, } \\
\text { labour }\end{array}$ & labour \\
\hline $\mathrm{A}_{9}$ & 26 & 0.4 & 10.0 & Fruit & 6.7 & 5 & 2 & 1 & labour, crop & 0 & cold \\
\hline $\mathrm{A}_{10}$ & 9 & 0.5 & 6.0 & Salad & 6.0 & 7 & 2 & 1 & soil & 0 & 0 \\
\hline $\mathrm{A}_{11}$ & 2 & 2.0 & 0 & Salad & 5.3 & 5 & 2 & 0 & labour, crop & 0 & 0 \\
\hline $\mathrm{A}_{12}$ & 25 & 1.5 & 4.0 & Fruit & 7.7 & 8 & 3 & 1 & 0 & 0 & 0 \\
\hline $\mathrm{A}_{13}$ & 16 & 1.0 & 1.0 & Fruit, vine & 7.0 & 7 & 3 & 2 & 0 & 0 & 0 \\
\hline $\mathrm{A}_{14}$ & 6.2 & 1.2 & 5.0 & Salad & 5.0 & 8 & 2 & 1 & crop, shelter & 0 & 0 \\
\hline $\mathrm{A}_{15}$ & 3 & 1.5 & 0.5 & Flower, SLT & 5.7 & 7 & 2 & 2 & labour, crop & shelter & shelter \\
\hline $\mathrm{A}_{16}$ & 8 & 1.2 & 3.0 & SLT, Fruit & 7.3 & 7 & 3 & 1 & 0 & 0 & 0 \\
\hline $\mathrm{A}_{17}$ & 8 & 1.0 & 6.0 & Salad & 5.7 & 7 & 2 & 2 & crop & 0 & 0 \\
\hline $\mathrm{B}_{1}$ & 8 & 2.2 & 0 & Fruit & 5.0 & 4 & 2 & 0 & labour & shelter & 0 \\
\hline $\mathrm{B}_{2}$ & 52 & 2.0 & 40.0 & Salad & 6.7 & 7 & 2 & 2 & 0 & wind & 0 \\
\hline $\mathrm{B}_{3}$ & 26 & 0.6 & 1.5 & Fruit, vine & 5.3 & 8 & 2 & 1 & crop & cold & 0 \\
\hline $\mathrm{B}_{4}$ & 13 & 1.5 & 9.5 & Salad, Fruit & 4.3 & 7 & 1 & 1 & labour & 0 & 0 \\
\hline $\mathrm{B}_{5}$ & 16 & 0.5 & 2.5 & Vine, fruit & 4.7 & 2 & 2 & 1 & labour & 0 & 0 \\
\hline $\mathrm{B}_{6}$ & 6 & 0.8 & 3.0 & Fruit & 2.0 & 3 & 1 & 1 & crop & 0 & 0 \\
\hline $\mathrm{B}_{7}$ & 16 & 1.5 & 0 & Fruit & 2.0 & 1 & 1 & 0 & crop & 0 & 0 \\
\hline $\mathrm{B}_{8}$ & 12 & 0.2 & 7.0 & Fruit & 5.7 & 6 & 1 & 1 & crop & 0 & 0 \\
\hline $\mathrm{B}_{9}$ & 4 & 4.0 & 0 & Salad & 8.0 & 7 & 2 & & 0 & 0 & 0 \\
\hline $\mathrm{C}_{1}$ & 4 & 1.0 & 3.0 & Salad & 5.3 & 8 & 2 & 1 & crop, shelter & 0 & 0 \\
\hline $\mathrm{C}_{2}$ & 10 & 0.6 & 2.0 & SLT, Vine & 4.7 & 6 & 2 & 1 & shelter & wind, shelter & 0 \\
\hline $\mathrm{C}_{3}$ & 18 & 0 & 1 & Lettuce & 1.0 & 3 & 0 & 1 & labour & wind, labour & labour \\
\hline $\mathrm{C}_{4}$ & 75 & 2.3 & 0 & Fruit & 3.0 & 1 & 1 & 0 & labour & 0 & 0 \\
\hline $\mathrm{C}_{5}$ & 8 & 0.6 & 0.2 & Fruit, vine & 5.7 & 3 & 2 & 1 & crop & 0 & 0 \\
\hline $\mathrm{C}_{6}$ & 7 & 0.7 & 2.0 & Fruit, vine & 4.7 & 4 & 2 & 1 & labour, crop & soil, wind & cold \\
\hline $\mathrm{C}_{7}$ & 48 & 0 & 48 & Salad & 5.7 & 8 & 0 & 2 & water & 0 & cold \\
\hline $\mathrm{C}_{9}$ & 20 & 6.0 & 3.5 & Salad & 7.0 & 7 & 3 & 2 & 0 & soil & 0 \\
\hline $\mathrm{C}_{10}$ & 13 & 0 & 2 & Fruit & 2.0 & 3 & 0 & 1 & labour & wind & 0 \\
\hline $\mathrm{C}_{11}$ & 3 & 0 & 3 & Salad & 5.0 & 6 & 0 & 2 & crop & soil & 0 \\
\hline $\mathrm{C}_{13}$ & 10 & 8.0 & 0 & Salad & 6.7 & 6 & 2 & 0 & 0 & shelter & 0 \\
\hline $\mathrm{C}_{14}$ & 10 & 1.0 & 1.0 & SLT, Fruit & 3.0 & 2 & 1 & 1 & labour & 0 & 0 \\
\hline
\end{tabular}

* Main crop in bold; SLT: soil-less tomato.

Restrictions on production period and salad types: crop: competition from other crops in salad plots; labour: competition from other crops for labour on a farm scale; water: restriction due to irrigation equipment; shelter: restrictions due to shelter characteristics (inadequately irrigated or poorly ventilated); 0: no restriction. 
the tolerable delay also depends on the season: disease and necrosis develop more rapidly in March-April because of the higher temperatures under the shelters than in winter.

To extend harvesting of a salad type beyond the window of about one week, growers stagger the planting of a given cycle on a given plot. All individuals planted in the course of a planting session are called a block. Thus, the number of blocks $\left(N_{-}\right.$Blocks $\left._{i k}\right)$ depends on plot size $\left(\mathrm{S}_{i}\right)$, work organisation (other plots harvested at the same time and with the same labour force) and the targeted spread of production (Fig. 2d). $N_{-}$Blocks $_{i k}$ is therefore dependent both upon sequencing and arbitration rules.

The effective surface for salad cultivation $\left(V d_{1}\right)$ interferes with the capacity to spread harvesting dates $\left(V d_{3}\right)$ because in the same manner as when choosing the number of salad types - the farmer must meet a minimum harvested volume target every week below which it is no longer viable to sell the produce.

\subsection{Planning and management}

The allocation of different salad types is planned through an iterative process. The interactions between $V d_{1}$ and $V d_{2}$ have already been mentioned. Likewise, if the farmer realises that he will find it difficult to reach the production targets for the different salad types $\left(V d_{3}\right)$, he can revise his determination of salad-cropping area and period $\left(V d_{1}\right)$, or the number of cycles per plot and per year $\left(V d_{2}\right)$ : for instance, reducing the number of cycles increases leeway in planting dates and provides greater flexibility than in a 3-cycle crop sequence.

But salad production, including that under shelters, remains susceptible to climatic variations which are often responsible for deviations from planned harvesting dates $(+/-4$ days for open field crops (Bruno and Papy, 1992), and on rare occasions even more). In particular, farms where salad cycles are planned to follow one another very rapidly are very susceptible to climatic variations. Under sheltered conditions, if the first two cycles are longer than planned, it may be impossible to crop the third one. Considering the entire farm, climatic variations may result in overlapping harvesting periods for different plots that are supposed to be harvested in succession. These modifications refer to crop real-time management. But given that such situations arise fairly frequently, they also refer to planning as some possible alternatives are already anticipated at the very start of the campaign (Aubry, 2000). In the particular case of salad, various modifications can be employed. For a given plot, the next cycle may be modified (one type of salad being replaced by another with a shorter cycle) or a third cycle may be abandoned. For the entire farm, harvesting dates may be revised or outside labour may be called in to shorten intercrop periods (Tordjman et al., 2004).

\subsection{Model evaluation procedure}

Using a survey in 38 farms, the validation procedure aimed to (i) assess the ability of the model to explain the diversity of salad multi-field cropping schedules between growers and (ii) identify among input variables the major key factors which determine the two output variables. The output variables $\mathrm{V}_{1}$ and $\mathrm{V}_{2}$ are not easily available in a large farm survey, since it would be necessary to register all the planting cycles of each plot for each farm. Therefore we used two derived variables for the evaluation procedure, which are correlated with $\mathrm{V}_{1}$ and $\mathrm{V}_{2}$ and are easier to collect: $\mathrm{V}_{1}$, the number of salad types and $\mathrm{V}_{2} *$, the maximum length of harvesting period.

The model in the present version cannot precisely quantify the variables, because only part of the decision rules have numerical data. However, it enables classifying each farm as having low, intermediate or high values of the two output variables. The validation process consisted of comparing the classification estimated with the model from the input variables obtained in the survey to that based on direct compilation of the output variables measured in the farm survey.

\section{Classification based on the model}

Classification for the number of salad types $\left(\mathrm{V}_{1} *\right)$ into 3 classes is first of all based on the developed surface area, calculated from the survey input data, as output of Boxes A and B (Fig. 1), and then on the particular characteristics of plots and growers' strategy (Box C). Thus, the value for $\mathrm{V}_{1} *$ calculation is the algebraic sum (Tab. V) of (a) a factor depending on $D e v \_S(+1$ to +3$),($ b, c \& e ) a factor equal to +1 if the farm is specialised in salad or soil-less crops, or if there are high-tech shelters on the farm or if plots have no constraints for a particular salad type, and (d) a factor equal to -1 for farms with only open fields or shelters since these have been shown to be limiting in Box C. In a similar manner, classification for the harvest period $\left(\mathrm{V}_{2} *\right)$ is first based on the developed surface area. Moreover, $\mathrm{V}_{2} *$ is increased for farms with no particular problem of work organisation or competition between crops which could reduce the harvesting period, and decreased for farms with only open fields or shelters (as a result of Boxes C and D).

\section{Classification based on the farm survey}

The real number of salad types $\mathrm{V}_{1}$ * indicated by growers during the survey (column 7, Tab. VI) was separated into three classes: up to 3 salad types for class I , 4 to 6 salad types for class II and 7 or more for class III. The real harvesting period $\mathrm{V}_{2} *$ (column 6 , Tab. VI) was also separated into three classes: $\leqslant 3$ months for class I, 3-6 months for class II and > 6 months for class III.

\section{RESULTS AND DISCUSSION}

In the Roussillon region, the number of salad types cultivated per farm $\left(\mathrm{V}_{1} *\right)$ varied from 1 to 8 , with $60 \%$ of the farms having 6 or more types (Tab. VI). As regards the harvesting pe$\operatorname{riod}\left(\mathrm{V}_{2} *\right), 84 \%$ of the farms produced for more than 3 months and $26 \%$ for more than 7 months.

In Table VII, the classes estimated by the model are compared with the classes from the survey; 26 farms for $\mathrm{V}_{1} *$ and 28 for $\mathrm{V}_{2} *$ among the 38 farms surveyed were correctly classified by the model. The error in classification was never bigger than one class, except for one farm for $\mathrm{V}_{1} *$. The differences 
Table VII. Confrontation between estimated and realised classes for $\mathrm{V}_{1} *$ and $\mathrm{V}_{2} *$.

(a) Number of salad types $\left(\mathrm{V}_{1} *\right)$

\begin{tabular}{ccccc}
\hline & \multicolumn{5}{c}{ Classes estimated by the model } \\
& Class I & Class II & Class III & total \\
\hline Real Class I (<4 types) & 4 & 4 & 0 & 8 \\
Class II (4-6 types) & 3 & 8 & 2 & 13 \\
Class III (> 6 types) & 1 & 2 & 14 & 17 \\
\hline Total & 8 & 14 & 16 & 38 \\
\hline (b) Harvest period $\left(\mathrm{V}_{2} *\right)$ & \multicolumn{5}{c}{} \\
\hline & Classes estimated by the model & \\
& Class I & Class II & Class III & total \\
\hline Real Class I $(\leqslant 3$ months) & 4 & 2 & 0 & 6 \\
Class II (3-6 months) & 4 & 16 & 1 & 21 \\
Class III (>6 months) & 0 & 3 & 8 & 11 \\
\hline Total & 8 & 21 & 9 & 38 \\
\hline
\end{tabular}

The figures indicate the number of farms of the sample.

between estimated and real classes can partially be explained by specific decision rules of the growers which are not included in the model at present. For example, the 3 growers $\mathrm{A}_{13}$, $\mathrm{B}_{3}$ and $\mathrm{B}_{9}$, cropping a large number of salad types on a limited developed surface area, effectively indicated during the interview that they have strengthened their diversification strategy for marketing reasons either to experiment with new markets with better prices $\left(A_{13}\right.$ and $\left.B_{3}\right)$ or because the farm $\left(B_{9}\right)$ was quasi-integrated into the commercial firm (Navarrete et al., 2006). Therefore they accepted to produce a small amount of each salad type ( $0.5 \mathrm{ha})$, and for $\mathrm{B}_{9}$ at each date (thus producing for 8 months). On the contrary, some growers indicated during the survey that they wanted to simplify sharply their salad cropping to one cycle to concentrate on orchards and vineyard $\left(\mathrm{B}_{6}\right)$ or tomatoes $\left(\mathrm{C}_{14}\right)$. Some others, even if they have no particular constraints under their shelters decided to use solarisation (thermal soil disinfection) or green fertilisers instead of the third cycle (grower $\mathrm{A}_{5}$ ). They therefore produced a large area per salad type (from 1 to $2 \mathrm{ha}$ ) and a smaller number of salad types than estimated.

The confrontation between model predictions and data as regards the number of salad types and the harvest period showed that the descriptive variables and the decision rules of the model were pertinent. The two output variables were heavily dependent upon the developed surface area devoted to salad and the division into open field or sheltered cropping. The other major variable consisted of the type of restrictions present on the farm, and their magnitude: whereas the range of salad types was primarily restricted by soil and climate conditions, the harvesting period was above all restricted by competition for labour or land. The two output variables were partially interrelated: farms producing over 8 months cultivated a medium or broad range of salad types, whereas those producing over only 3 months planted a more restricted range.

The analysis allowed us to validate the general structure of the model put forward by Aubry (2000) and Maxime et al. (1995), and also to adapt certain modules to match market- gardening specificity. This was the case for criteria such as the number of salad cycles per year and per plot, and the types of salads cropped, which are most important in market gardening. On the other hand, criteria such as "previous crop" and "return time" proved to be less important in our study, at least at the time the survey was conducted. An explanation may be that in a region specialised in salad production, the cropped area is very similar to the area suitable for cultivation and the cropping period is very similar to the period suitable for cultivation. By contrast, in other market garden farms subject to similar soil and climate conditions but directed more to strawberry production (Carpentras basin, Vaucluse), salad is cultivated at best only one winter out of two with the plot being alternately occupied by strawberry and salad vegetables (Bellon et al., 1999). Likewise, when salad is included in an arable cropping system, or in organic market-gardening systems, it is cropped once a year on any given plot, with a return time strictly set at more than 1 year (Beliard, 2003). Also, in coming years we may witness a lengthening of salad return times even in intensive salad-producing areas caused by the diminished possibility of using chemical treatments. For example, a return time of 5 years is recommended to avoid Sclerotinia in heavily infected soils (Blancard et al., 2003). If more importance were to be given in the decision-making model to controlling soil health, this would doubtless lead to adopting a representation closer to that proposed by Maxime et al. (1995) in arable crops and to the development of decision-making rules for choosing crop successions and return times with consideration of pest and disease carry-over effects.

We focused our analysis on the individual farm, considering that it is primarily at this level that crop planting decisions are taken. However, higher levels of organisation interfere with the decisions taken on each farm (Le Bail, 2004; Navarrete et al., 2006). This may explain the differences between estimated and real classes. For example, the contracts the marketing structures propose to growers to reduce the risks at the start and end of the cropping period or for certain types of susceptible 
salad (young leaves and frisee Très Fine Maraîchère) could explain why the production strategies employed by certain farms are difficult to elucidate on the sole basis of the model's variables. Some marketing structures even impact directly on key factors such as labour, by themselves providing labour through an employers' group, and sheltered area available, by financial incentives for market gardeners to build shelters, in order to change farmers' production strategies. These factors have not been integrated into the model but have been comprehensively analysed by Navarrete et al. (2006).

\section{CONCLUSION}

Our aim was to model the farmer's decision-making process for two key factors for commercialisation: planning of the developed areas allocated to the different salad types and range of the harvest dates. In the farm sample, the number of salad types cultivated per farm varied from 1 to 8 and the harvesting period from 3 to 7 months. Our results demonstrate that the model can explain a substantial part of this variability, 26 and 28 farms among 38, respectively, being correctly classified by the model for the two variables. The model gives the opportunity to identify the types of farms where the modification of constraints by the means of agronomic innovations may change their ability to produce various types of salads during a long period, which is a strong commercial demand. It can be used with farmers to determine the leeway available to them for the introduction of technical changes in salad cropping: shifts in planting dates, changes in the number of cycles per plot, introduction of new salad types, etc., and for examining the compensation possibilities among the different variables, e.g. between surface areas of open field and under shelter, or between cultivated surface area and number of cycles per plot. The model could therefore be used by technical advisors working on the scale of the salad vegetable supply area. They must identify to what extent each supplier is able to innovate in enlarging harvesting periods or number of salads, in order to co-ordinate the different types of farming systems to offer the best combination of these two variables on the supply area scale. As for classical decision support systems (Chatelin et al., 2005) the model we proposed could be associated, as a "management module", with a crop model simulating salad yield and quality formation to compare the impacts of different technical choices. Finally, from a theoretical standpoint, this model shows that the representation established for arable cropping systems is for the most part valid when applied to the very different market garden systems, which suggests that the model is generic.

Acknowledgements: We wish to thank C. Aubry for her critical comments on the article and S. Tordjman for data acquisition on the different farms.

\section{REFERENCES}

Agreste (2001) Recensement agricole fruits et légumes de PyrénéesOrientales, octobre 2001.
Aubry C. (2000) Une modélisation de la gestion de production dans l'exploitation agricole, Revue française de gestion, July-August, pp. 34-46.

Aubry C., Paillat J.M., Guerrin F. (2002) Modélisation conceptuelle de la gestion des matières organiques issues des élevages dans les exploitations agricoles. L'exemple de l'Ile de la Réunion, in: Actes du séminaire "Modélisation des flux de biomasse et des transferts de fertilité ", 19-22 June 2002, Montpellier, Cirad.

Aubry C., Papy F., Capillon A. (1998) Modelling decision-making processes for annual crop management, Agr. Syst. 56, 45-65.

Bellon S., Bertuzzi P., Musset J., Vannier S., Mirambeau C., Laques A.E., Derioz P. (1999) Nitrate pollution of ground waters in a small Mediterranean region, in: Rural and farming systems analyses, environmental perspectives, in: Doppler W., Koutsouris A. (Eds.), Margraf Verlag, proceedings of the 3rd European symposium of AFSRE, Hohenheim, Germany, 25-27/03/1998.

Beliard E. (2003) Maladies et ravageurs de la laitue et chicorée à salade en agriculture biologique, Fiche technique, ITAB, Paris.

Blancard D., Lot H., Maisonneuve B. (2003) Maladies des salades, identifier, connaître et maîtriser, INRA Ed., Paris, 375 p.

Bruno J.F., Papy F. (1992) Mieux gérer la sole de laitue dans la vallée de la Seine, Cahiers Agric. 1, 95-100.

Carberry P.S., Hochman Z., McCown R.L., Dalgliesh N.P., Foale M.A., Poulton P.L., Hargreaves J.N.G., Hargreaves D.M.G., Cawthray S., Hillcoat N., Robertson M.J. (2002) The FARMSCAPE approach to decision support: farmers', advisers', researchers' monitoring, simulation, communication and performance evaluation, Agr. Syst. 74, 141-177.

Cerf M. (1996) Approche cognitive de pratiques agricoles : intérêts et limites pour les agronomes, Natures, Sciences et Sociétés 4, $327-340$

Chatelin M.H, Mousset J. (1997) Decision support for work organisation and choice of equipment, in: Ten-Berge H.F., Stein A. (Eds.), Model based decision support in agriculture, ABDLO, Research Institute for Agrobiology and Soil Fertility, Wageningen, NLD, pp. 51-64.

Chatelin M.H., Aubry C., Poussin J.C., Meynard J.M., Masse J., Verjux N., Gate P., Bris X.L. (2005) DeciBle, a software package for wheat crop management simulation, Agr. Syst. 83, 77-99.

Chaux C., Foury C. (1994) Productions légumières. T.2, Légumes feuilles, tiges, fleurs, racines, bulbes, Agriculture d'aujourd'hui, Sciences Techniques Applications, Lavoisier, Paris, France.

de Tourdonnet S. (1998) Maîtrise de la qualité et de la production nitrique en culture de laitue sous abri plastique: diagnostic et modélisation des effets des systèmes de culture, Thesis INAPG, Paris, 192 p.

Dogliotti S., Rossing W.A.H., van Ittersum M.K. (2003) ROTAT, a tool for systematically generating crop rotations, Eur. J. Agron. 19, $239-250$.

Dounias I., Aubry C., Capillon A. (2002) Decision-making processes for crop management on African farms. Modelling from a case study of cotton crops in northern Cameroon, Agr. Syst. 73, 233-260.

El-Nazer T., McCarl B.A. (1986) The choice of crop rotation: a modelling approach and case study, Am. J. Agr. Eco. 68, 127-136

Goisque M.J. (1994) Calendriers de plantation, Salade haute définition, Cahier hors-série Fruits et Légumes, Echo des MIN, 44-47.

Jones J.W., Hoogenboom G., Porter C.H., Boote K.J., Batchelor L., Hunt L.A., Wilkens P.W., Singh U., Gisjman A.J., Ritchie J.T. (2003) The DSSAT cropping system model, Eur. J. Agron. 18, 235-265. 
Keating B.A., Carberry P.S., Hammer G.L., Probert M.E., Robertson M.J., Holzworth D., Huth N.I., Hargreaves J.N.G., Meinke H., Hochman Z., McLean G., Verburg K., Snow V., Dimes J.P., Silburn M., Wang E., Brown S., Bristow K.L., Asseng S., Chapman S., McCown R.L., Freebairn D.M., Smith C.J. (2003) An overview of APSIM, a model designed for farming systems simulation. Modelling cropping systems: science, software and applications. Second special issue with selected papers based on the 2nd International Symposium on Modelling Cropping Systems, Florence, Italy, 16-18 July, 2001, Eur. J. Agron. 18, 267-288

Lagier J. (1994) Laitues sous abris plastiques ; maîtrise des conditions climatiques, Salade haute définition 1994, 60-65.

Le Bail M. (2004) A design for a local crop supply system as a quality management territory, in: Jacobsen S.E. et al. (Eds.), European agriculture in a global context, European Society of Agronomy, Copenhaguen, Denmark, pp. 527-528.

Leroy P., Balas B., Deumier J.M., Jacquin C., Plauborg F. (1996) Water management at farm level, in: The management of limited resources in water. Their agronomic consequences, Final report of EU CAMAR 8001CT91-0109 project, pp. 89-151.

Maxime F., Mollet J.M., Papy F. (1995) Aide au raisonnement de 1'assolement en grande culture, Cahiers Agric. 4, 351-362.

Navarrete M., Le Bail M., Papy F., Bressoud F., Tordjman S. (2006) Combining leeway on farm and supply basin scales to promote technical innovations in lettuce production, Agron. Sustain. Dev. $26,77-87$.

Nesme T., Lescourret F., Bellon S., Plenet D., Habib R. (2003) Relevance of orchard design issuing from growers' planting choices to study fruit tree cropping systems, Agronomie 23, 651-660.

Oniflhor, Ctifl, Fnpl (2000) Observatoire des exploitations légumières, Paris.
Papy F., Attonaty J.M., Laporte C., Soler L.-G. (1988) Work organisation simulation as a basis for farm management advice, Agr. Syst. 27, $295-314$

Paul V.H., Sultana C., Jouan B., Fitt B.D.L. (1991) Strategies for control of diseases on linseed and fibre flax in Germany, France and England, Aspects Appl. Biol. 28, 65-70.

Rossing W.A.H., Jansma J.E., De Ruijter F.J., Schans J. (1997) Operationalizing sustainability: exploring options for environmentally friendly flower bulb production systems, Eur. J. Plant Pathol. 103, 217-234.

Ryder E.J. (1999a) Production methods, in: Lettuce, endive and chicory, CABI publishing, Wallingford, UK, pp. 79-96.

Ryder E.J. (1999b) Harvest and post harvest methods, in: Lettuce, endive and chicory, CABI publishing, Wallingford, UK, pp. 97-107.

Sebillotte M., Soler M.G. (1990) Les processus de décision des agriculteurs. Acquis et questions vives, in: Brossier J., Vissac B., Le Moigne J.L. (Eds.), Modélisation systémique et systèmes agraires, Paris, INRA, pp. 88-102.

Seigneur K. (1996) Déterminisme de la stratégie de cultures de salade en Roussillon. Importance des structures commerciales, Mémoire de fin d'étude d'ingénieur, INAPG, Paris, 88 p.

Ten Berge H.F.M., van Ittersum M.K., Rossing W.A.H., van de Ven G.W.J., Schans J., van de Sanden P.A.C.M. (2000) Farming options for the Netherlands explored by multi-objective modelling, Eur. J. Agron. 13, 263-277.

Thicoïpe J.P. (1997) Laitues, Ctifl, Paris.

Tordjman S., Navarrete M., Papy F. (2004) Les formes de coordination technique entre des structures de première mise et leurs apporteurs, Cahier Agric. 14, 479-484.

Wurr D.C.E., Fellows J.R., Suckling R.F. (1988) Crop continuity and prediction of maturity in the crisp lettuce variety Saladin, J. Agr. Camb. 111, 481-486. 